\title{
Autophagy in Myelinating Glia
}

\author{
Jillian Belgrad, ${ }^{1}$ @Raffaella De Pace, ${ }^{2}$ and R. Douglas Fields ${ }^{1}$ \\ ${ }^{1}$ Section on Nervous System Development and Plasticity and ${ }^{2}$ Section on Intracellular Protein Trafficking, Eunice Kennedy Shriver National Institute of \\ Child Health and Human Development, National Institutes of Health, Bethesda, Maryland 20892
}

Autophagy is the cellular process involved in transportation and degradation of membrane, proteins, pathogens, and organelles. This fundamental cellular process is vital in development, plasticity, and response to disease and injury. Compared with neurons, little information is available on autophagy in glia, but it is paramount for glia to perform their critical responses to nervous system disease and injury, including active tissue remodeling and phagocytosis. In myelinating glia, autophagy has expanded roles, particularly in phagocytosis of mature myelin and in generating the vast amounts of membrane proteins and lipids that must be transported to form new myelin. Notably, autophagy plays important roles in removing excess cytoplasm to promote myelin compaction and development of oligodendrocytes, as well as in remyelination by Schwann cells after nerve trauma. This review summarizes the cell biology of autophagy, detailing the major pathways and proteins involved, as well as the roles of autophagy in Schwann cells and oligodendrocytes in development, plasticity, and diseases in which myelin is affected. This includes traumatic brain injury, Alexander's disease, Alzheimer's disease, hypoxia, multiple sclerosis, hereditary spastic paraplegia, and others. Promising areas for future research are highlighted.

\section{Introduction}

Autophagy, derived from the Greek words phagos meaning "eat" and auto meaning "self," is an essential and conserved cellular process that drives the capture and recycling of proteins, pathogens, and organelles, allowing their removal from the cytosol and degradation in the lysosome (Levine and Klionsky, 2004; Eskelinen and Saftig, 2009; Dikic and Elazar, 2018). Well characterized in neurons (Lee, 2012; Wong and Holzbaur, 2015; Maday and Holzbaur, 2016; Menzies et al., 2017), autophagy in glial cells has been much less studied. This is surprising, considering the important involvement of autophagy in development, disease, and response to injury, and the essential functions of glia in these processes. Examples that will be discussed in this review include the new evidence of autophagy during oligodendrocyte development, in peripheral myelin compaction, and in facilitating myelin clearance after nerve injury. The functions of autophagy in myelinating glia (Schwann cells and oligodendrocytes) are even less well known than for astrocytes and microglia, yet the formation of myelin membrane and removal of myelin debris after injury involve robust transport and recycling of proteins, membrane lipids, organelles; cytoskeletal and membrane remodeling; and endocytosis and exocytosis: processes in which autophagy is critical in other cells. This review summarizes current information on autophagy in myelinating glia in association with a wide range of biological functions and in nervous system disorders, and it highlights promising areas for future research.

Received May 28, 2019; revised 0ct. 17, 2019; accepted Nov. 8, 2019.

This work was supported by National Institutes of Health Intramural Research Grants ZIAHD000713-22 and ZIAHD001607. We thank Dr. Juan S. Bonifacino for helpful discussion of the manuscript.

The authors declare no competing financial interests.

Correspondence should be addressed to R. Douglas Fields at fieldsd@mail.nih.gov.

https://doi.org/10.1523/JNEUROSCI.1066-19.2019

Copyright $\odot 2020$ the authors
While other reviews have described autophagy signaling in detail (Glick et al., 2010; Dikic and Elazar, 2018), our goal is to synthesize mechanisms of autophagy in myelinating glia in the CNS and PNS during lifelong development, plasticity, injury, and disease. We first review the major components and interactions along the autophagy pathways. We then discuss studies that identify and manipulate autophagic processes in Schwann cells and oligodendrocytes across developmental and injury states. In doing so, we hope to underscore the crucial contribution that autophagy plays in myelinating glia and how these new insights may be targeted in therapies for neurological disease and injury.

\section{Autophagy process and pathways}

At least three forms of autophagy have been identified: (1) chaperone-mediated autophagy (Dice, 1990), which targets unfolded cytosolic proteins with chaperone proteins and translocates them through the lysosomal membrane; (2) microautophagy (Marzella et al., 1981), in which the lysosomal membrane undergoes local rearrangements to engulf portions of cytoplasm; and (3) macroautophagy (De Duve and Wattiaux, 1966), which, through double-membrane organelles called phagosomes, engulfs cellular material that is degraded and recycled. Microautophagy is induced by nitrogen starvation or rapamycin treatment (Li et al., 2012) and can be selective or bulk engulfment (Sahu et al., 2011). Microautophagy happens locally on the surface of lysosomes and only involves a small portion of these organelles. This review focuses on macroautophagy, henceforth referred to as autophagy.

Macroautophagy (De Duve and Wattiaux, 1966) can be induced by a number of signals (e.g., hypoxia, nutrient depletion, cellular damage, production of oxygen reactive species). Following induction, the cell starts to protrude double-membrane organelles called phagosomes, to surround and engulf the material targeted for degradation. The origin of the cup-shaped double membrane is not well understood, and is still a matter of intense 


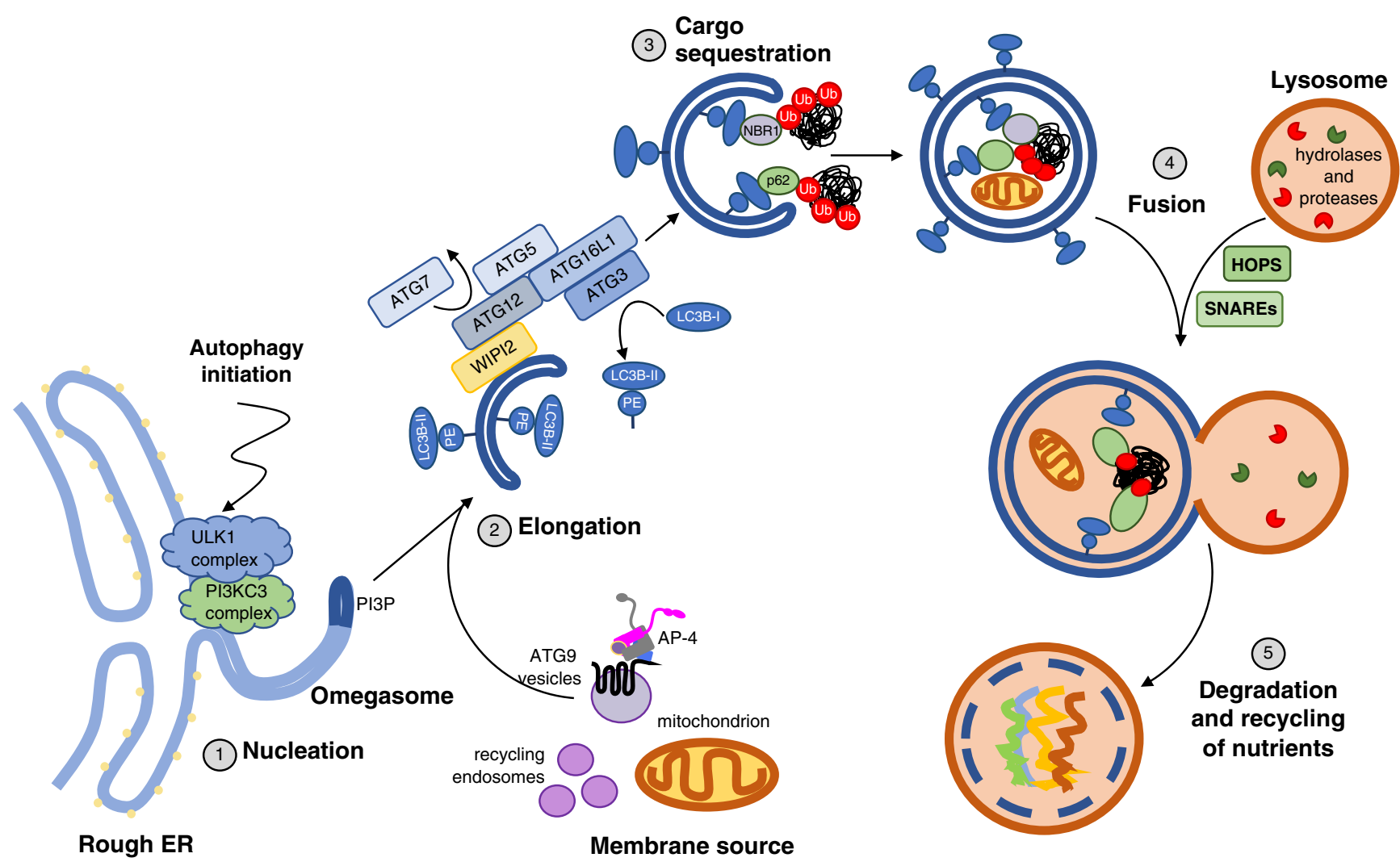

Figure 1. Schematic representation of autophagic pathway. Cellular stress, such as amino acid starvation, targets the ULK1 complex, which then phosphorylates the PI3KC3. This triggers local phosphatidylinositol-3-phosphate (PI3P) production and nucleation of the omegasome. PI3P effectors, such as WIPI2, are then recruited, and interact with the ATG-7-ATG12-ATG5-ATG16L1-ATG3 LC3B-conjugation system. This complex, through ATG3, mediates phosphatidylethanolamine (PE) lipidation of ATG8 family proteins (e.g., LC3B), enabling their recruitment to the phagophore membrane. Membranes contributing the phagophore elongation can have different cellular origins, including recycling endosomes, mitochondria, and ATG9A-containing vesicles exported through AP-4. In selective autophagy, lipidated LC3B-II is critical for sequestration of cytosolic poly-ubiquitylated (Ub) aggregates through receptors, such as p62 and NBR1. The fusion of the mature, sealed, double-membrane autophagosome with lysosomes is mediated by SNARE and HOPS complex. Lysosomal hydrolases and proteases can then degrade the autophagic cargo and nutrients, making lipids and amino acids available for reuse in the cell.

debate. Some recent in silico work proposes that the double membrane is the result of progressive fusion of vesicles, followed by protein-mediated remodeling (Bahrami et al., 2017). However, macroautophagy does not always involve double-membraned structures (Mijaljica and Devenish, 2013).

In most cells, basal levels of autophagy help maintain the integrity of intracellular organelles. However, autophagy is strongly induced under starvation (Hosokawa et al., 2009; Kim et al., 2011), hypoxia (Semenza, 2010), aging (Mizushima and Komatsu, 2011), cancer (Galluzzi et al., 2015), and infection (Gomes and Dikic, 2014), reflecting a critical role of recycling membrane, organelles, and macromolecules during these processes. Macroautophagy consists of five main steps: (1) initiation and nucleation, (2) elongation of the nascent double membrane, (3) cargo sequestration, (4) fusion of the mature autophagosome with lysosomes, and (5) recycling of nutrients (Dikic and Elazar, 2018). The autophagy-related (ATG) proteins, several of which have been identified and are encoded by different $A t g$ genes (Dikic and Elazar, 2018), are among the most important proteins for this process. The fundamentals of the autophagy pathway are illustrated in Figure 1.

Different cellular compartments have been described as the origin for the autophagy membrane: the first organelle proposed as source for autophagosomal membrane is the endoplasmic reticulum (ER) (Axe et al., 2008). More specifically, it has been suggested that the ER-mitochondrion interface domains donate lipids to forming phagosomes (Hailey et al., 2010). In particular, work done in eukaryotic cells shows that the outer membrane of the mitochondria must be physically connected with the ER during starvation to share phosphatidylethanolamine lipids with the nascent autophagosome and promote the lipidation of microtubule-associated protein light chain $3 \mathrm{~B}$ I(LC3B-I) to LC3B-II (Hailey et al., 2010). The plasma membrane has also been hypothesized to contribute to the formation of autophagosomes, involving the heavy chain of clathrin and ATG16L1 protein (Ravikumar et al., 2010). The Golgi has also been suggested as a possible independent donor of membrane forming autophagosomes (Geng et al., 2010; Ohashi and Munro, 2010). There is strong scientific evidence for each these processes, and therefore it is possible that each of these compartments participates in the formation of the autophagic membrane, depending on the condition or cell type.

Following amino acid starvation, the unc-51 like autophagyactivating kinase 1 (ULK1) forms a complex with ATG13, FIP200, and ATG101 (Hara et al., 2008; Ganley et al., 2009), and this promotes activation of the Class III phosphoinositide 3-kinase (PI3KC3) complex, consisting of VPS34, VPS15, Beclin1, AMBRA1, and ATG14L proteins (Fimia et al., 2007; Jean and Kiger, 2014). Activation of the PI3KC3 complex produces phosphatidylinositol 3-phosphate and catalyzes the nucleation and elongation of the preautophagosomal structure (Russell et al., 2013) with the consequent recruitment of additional ATG proteins and autophagy-specific phosphatidylinositol-3-phosp- 
hate effectors. These nucleation sites are known as omegasomes because of their $\omega$-shaped profile (Lamb et al., 2013).

Addition of membrane during this process depends on further mobilization of the transmembrane protein ATG9A (Mari et al., 2010; Orsi et al., 2012; Zhou et al., 2017). During expansion of the preautophagosomal structure, the ATG12-ATG5-ATG16L1 complex is recruited and acts as an E3-like ligase to mediate the conjugation of the LC3B and/or its family members GATE16 and GABA receptor-associated protein (GABARAP) to phosphatidylethanolamine. This enables the protein complex to associate with the autophagosomal membrane (Fig. 1). After closure of the phagophore, LC3B-II remains on what will become the inner surface of the autophagosome. Therefore, LC3B protein is a widely used marker for identifying autophagosomes and autophagy flux in cells. The association of lipidated LC3B (also called LC3B-II) and GABARAP proteins with the autophagic membrane is reversible and is mediated by ATG4 (Pengo et al., 2017).

Basal autophagy is capable of extraordinary cargo selectivity. Selective autophagy pathways use cytosolic cargo receptors and adaptors, such as SQSTM1/p62 (Shaid et al., 2013) and neighbor of BRCA1 gene 1 (NBR1) (Stolz et al., 2014). These receptor proteins bind ubiquitylated protein aggregates to ATG8 family members, including LC3B-II (Pankiv et al., 2007; Birgisdottir et al., 2013), and sequester protein aggregates within the lumen of the forming autophagosome.

Fusion of the mature autophagosome with lysosomes is mediated by the STX17-VAMP8-SNAP29 trans-SNARE complex, and an ARL8B-dependent recruitment of the homotypic fusion and protein sorting complex to lysosomes (Itakura et al., 2012; Jia et al., 2017). Inside the fused autophagolysosome, the cytosolic cargo is finally hydrolyzed. This digestion and recycling allow lipids and amino acids to be available for reuse in the cell.

Methods used to measure and interpret dynamics along the autophagy pathway have long been discussed and debated (Klionsky et al., 2012). Manipulation of autophagy is closely linked with alterations in lysosomes and the ubiquitin proteasome. For that reason, pharmacologically manipulating both proteasome and lysosomal activity reveals mechanisms about autophagy and the basic contributions that protein and lipid recycling play in the cell. Importantly, autophagy can be measured at one time point, termed steady-state autophagy, or as a dynamic activity over time, termed autophagy flux. There are a number of methods currently used to assess both the steady state and autophagic flux. We have summarized some of these methods, including their interpretation and limitations, in Table 1.

\section{Autophagy in myelinating glia}

Autophagy in the CNS has been studied predominantly in neurons; it has been largely unexplored in glial cells. This is of interest if we consider that regulation of autophagy seems to differ in neuronal and non-neuronal cells, since few autophagosomes are found in healthy neurons (Mizushima et al., 2004; Boland et al., 2008). This suggests that neurons have a low basal level or a quick turnover of autophagy. Moreover, known inducers of autophagy in non-neuronal cells (e.g., rapamycin, nutrient starvation, and lithium chloride) can fail to increase autophagosome formation in primary neurons (Mizushima et al., 2004; Komatsu et al., 2007; Mitra et al., 2009). Rapamycin promotes autophagy by inhibiting the mammalian target of rapamycin (mTOR), a protein that balances energy input versus energy expenditure of cells through accessing nutrient availability and stress signals (Jung et al., 2010; Dunlop and Tee, 2014). The lack of increased autophagosome formation with rapamycin or known inducers of autophagy in primary neurons indicates that neurons differ from nonneuronal cells in both mTOR-dependent and -independent autophagy-inducing pathways because mTOR inhibition is considered a classical autophagy inducer. Evidence of active glial cell autophagy under the same conditions when neuronal autophagy was found to be absent highlights the importance of studying the autophagic process in glial cells, especially when considering neurodegenerative diseases.

Myelinating glia undergo robust morphological and functional changes, including vast lipid and protein production and membrane compaction; and for that reason, autophagic processes are emerging as an essential component to Schwann cell and oligodendrocyte function in development, injury, and disease. When considering autophagy in myelinating glia, it is important to first understand how Atg transcripts vary in expression in these cells across development. Each ATG-protein type has a unique function, and the specific functions of each are reviewed extensively by Dikic and Elazar (2018). The literature to date does not have a centralized list of Atg expression across oligodendrocyte development, which could be used to identify ideal autophagy-related therapeutic candidates in oligodendrocytes. To address this need, a table of the relative expression of Atgs transcripts across oligodendrocyte development is presented in Table 2. Protein expression of various ATG subtypes, most frequently ATG5, has also been reported in oligodendrocytes' cytoplasm (Ohri et al., 2018; Bankston et al., 2019). The subcellular distribution of autophagy proteins in morphologically complex cells of the oligodendrocyte lineage is illustrated in Figure 2, which shows representative images of adaptor protein 4 (AP-4) expression and its cargo, ATG9A, in premyelinating oligodendrocytes. There is robust expression of AP-4 and ATG9A across the oligodendrocyte processes in the unstressed in vitro oligodendrocyte lineage cell.

Based on RNA-seq data (Zhang et al., 2014) (Table 2), the most highly expressed Atgs in oligodendrocytes are Atg9a, Atg12, and Atg3. Interestingly, Atg expression varies across oligodendrocyte development, with Atg expression usually decreasing as the cell matures. While extensive RNA-seq data reporting Atgs for Schwann cells are not available at this time, multiple studies have demonstrated expression of Atgs in Schwann cells (GomezSanchez et al., 2015; Jang et al., 2015, 2016, 2017).

\section{Autophagy in development of myelinating glia}

Autophagy plays a key role in the maturation and structural plasticity of Schwann cells (Jang et al., 2015) and oligodendrocytes (Bankston et al., 2019). Autophagy is active in Schwann cells during organelle biogenesis and is used to promote myelin compaction through removing excess cytoplasm (Jang et al., 2015). The ability of autophagy to regulate appropriate cytoplasm levels has been suggested by studies in oligodendrocytes as well (Bankston et al., 2019). Indeed, axons myelinated by $\mathrm{Atg}^{-/-}$oligodendrocytes have larger G-ratio measurements (thicker myelin sheaths) compared with WT oligodendrocytes (Bankston et al., 2019) because the myelin formed by $\operatorname{Atg} 5^{-/-}$oligodendrocytes was loosely compacted with pockets of cytoplasm remaining. The role of autophagy in cytoplasm decompaction has interesting implications in the field of myelin plasticity, for example, in adults, where the number of myelin wraps can change over the course of weeks (Dutta et al., 2018). The ability of oligodendrocytes to quickly either compact additional wraps or remove wraps 
Table 1. Common methods used to detect and analyze the autophagic process

\begin{tabular}{|c|c|c|c|}
\hline Method & Interpretation & Method limitations & Select references \\
\hline FluoroMyelin ${ }^{a}$ and $\mathrm{pHrodo}^{b}$ & $\begin{array}{l}\text { Demonstrates lysosomal storage accumulation and pH } \\
\text { level }\end{array}$ & $\begin{array}{l}\text { Not clearly indicative of which step of the au- } \\
\text { tophagy pathway is affected, but only of the } \\
\text { general physiological state of lysosomes }\end{array}$ & Brosius Lutz et al. (2017) \\
\hline \multirow[t]{5}{*}{ LC3B-I and LC3B-II ratio and protein expression ${ }^{a, b}$} & $\begin{array}{l}\text { LC3B-II is degraded during autophagy flux; therefore, } \\
\text { altered LC3B levels can indicate the following: }\end{array}$ & $\begin{array}{l}\text { A Western blot of the LC3B-II/I ratio cannot be } \\
\text { used to assay autophagy flux unless perturba- } \\
\text { tion of autophagy in time is analyzed }\end{array}$ & Gomez-Sanchez et al. (2015) \\
\hline & (1) Higher production of the LC3B-I protein & & Marinelli et al. (2014) \\
\hline & $\begin{array}{l}\text { (2) Activation of autophagy (increased LC3B-I lipida- } \\
\text { tion into LC3B-II) }\end{array}$ & & Huang et al. (2016) \\
\hline & (3) Defective autophagy (if autophagy is impaired and & & Shi et al. (2013) \\
\hline & $\begin{array}{l}\text { LC3B-II degradation does not occur, LC3B-II accu- } \\
\text { mulates) }\end{array}$ & & \\
\hline \multirow[t]{5}{*}{ Expression of autophagic proteins ${ }^{b}$} & Commonly used to increase autophagy activity & $\begin{array}{l}\text { Overexpression can lead to protein aggregation } \\
\text { independent of autophagy (Kuma et al., 2007) }\end{array}$ & Zhang et al. (2018) \\
\hline & & & Pyo et al. (2013) \\
\hline & & & Oz-Levi et al. (2012) \\
\hline & & & Muñoz-Galdeano et al. (2018) \\
\hline & & & Shi et al. (2013) \\
\hline \multirow[t]{3}{*}{ Transmission electron microscopy (TEM) ${ }^{a}$} & $\begin{array}{l}\text { Microscopy used to identify the presence of autopha- } \\
\text { gosomes directly and quantitively }\end{array}$ & Unable to analyze dynamic turnover & Chen et al. (2016) \\
\hline & & & Marinelli et al. (2014) \\
\hline & & & Huang et al. (2016) \\
\hline RFP-EGFP-LC3B & Indicates dynamic LC3B maturation & $\begin{array}{l}\text { Overexpression can lead to formation of LC3B } \\
\text { aggregates, independent of autophagy. Due } \\
\text { to the high molecular weight of RFP and GFP, } \\
\text { this construct cannot be used to distinguish } \\
\text { LC3B-I and - II in Western blotting. }\end{array}$ & Kimura et al. (2007) \\
\hline \multirow[t]{4}{*}{$\begin{array}{l}\text { Global or cell-specific deletion of autophagy- } \\
\text { related genes }{ }^{a, b}\end{array}$} & $\begin{array}{l}\text { Commonly used method to interrupt normal au- } \\
\text { tophagy function, also used to understand the } \\
\text { physiological role of a protein of interest in the } \\
\text { autophagy process }\end{array}$ & $\begin{array}{l}\text { Some gene deletion could cause lethality in early } \\
\text { stages. Method facilitates a steady-state } \\
\text { analysis rather than autophagy flux. }\end{array}$ & Bankston et al. (2019) \\
\hline & & & Jang et al. (2015) \\
\hline & & & Ohri et al. (2018) \\
\hline & & & Kuma et al. (2017) \\
\hline \multirow[t]{3}{*}{ Transgenic GFP-LC3B mice ${ }^{b}$} & Widely used to monitor autophagy in vivo & Autophagy flux in the animal would vary by & Mizushima et al. (2004) \\
\hline & & $\begin{array}{l}\text { tissue type and organ system. Therefore, more } \\
\text { variables to consider compared with cell } \\
\text { culture. }\end{array}$ & \\
\hline & & & Kuma et al. (2017) \\
\hline
\end{tabular}

${ }^{a}$ Methods used to monitor steady-state autophagy.

${ }^{b}$ Methods that allow measurement of autophagic flux.

Table 2. Expression of autophagy-related (Atg) transcripts across oligodendrocyte development $^{a}$

\begin{tabular}{llll}
\hline $\begin{array}{l}\text { Autophagy-related } \\
\text { (Atg) gene name }\end{array}$ & $\begin{array}{l}\text { Oligodendrocyte } \\
\text { progenitor cell }\end{array}$ & $\begin{array}{l}\text { Newly formed } \\
\text { oligodendrocyte }\end{array}$ & $\begin{array}{l}\text { Myelinating } \\
\text { oligodendrocyte }\end{array}$ \\
\hline Atg3 & +++ & +++ & ++ \\
Atg4a & - & - & - \\
Atg4b & ++ & ++ & ++ \\
Atg4c & + & ++ & ++ \\
Atg4d & + & + & + \\
Atg5 & ++ & + & + \\
Atg7 & + & + & + \\
Atg9a & ++++ & ++++ & +++ \\
Atg10 & + & - & - \\
Atg12 & +++ & ++ & + \\
At13 & ++ & ++ & ++ \\
Atg14 & + & + & - \\
\hline
\end{tabular}

a-, 0-2 FPKM; +, 2-10 FPKM; ++, 10-20 KPKM; +++, 20-30 FPKM;,$++++ 30+$ FPKM. Table generated from RNA-seq data collected and made available by Zhang et al. (2014). under nondisease states indicates that there must be ongoing physiological control of autophagy in mature oligodendrocytes throughout life. Given the role that autophagy plays in promoting structural plasticity of Schwann cells, oligodendrocyte autophagy during development and across adulthood presents an intriguing path of study.

Bankston et al. (2019) demonstrate that autophagy protein ATG5 is also necessary for oligodendrocyte development. The researchers present evidence of increased autophagic flux, measured by LC3B-II/I levels and autophagosome puncta, in the distal processes of oligodendrocytes during cell differentiation. The authors also show that animals in which Atg5 was knocked out selectively in cells of the oligodendrocyte lineage had reduced levels of MBP in the corpus callosum, a lower percentage of myelinated axons, and abnormal myelin compaction. Further evidence for the importance of autophagy in promoting oligodendrocyte differentiation is that activation of autophagy with the autophagy induction peptide Tat-beclin 1 significantly increased the length of myelin segments in an oligodendrocyteneuron coculture. Conversely, inhibition of autophagy by disrupting autophagosome closure with the drug KU559533 or 

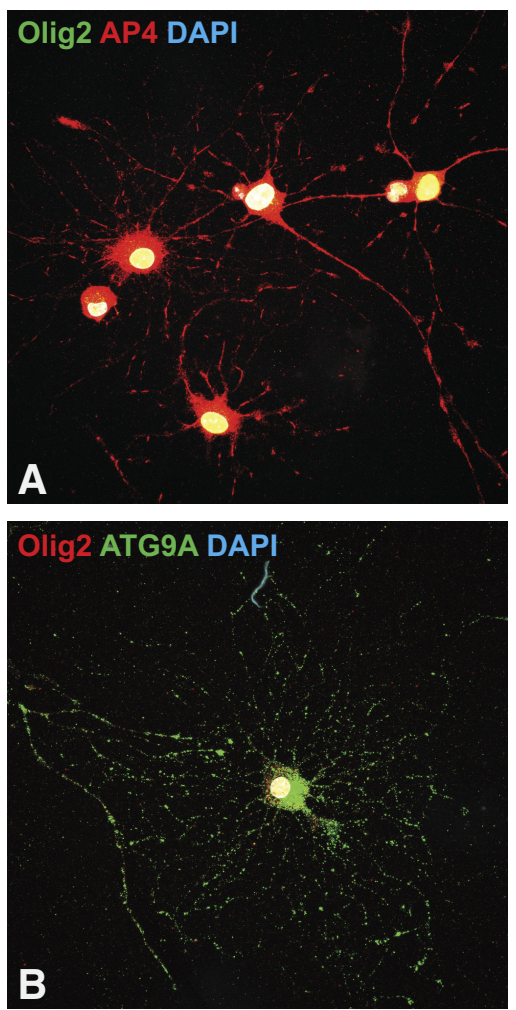

Figure 2. Autophagy protein expression in oligodendrocyte lineage cells. Cells are premyelinating oligodendrocyte lineage cells cultured from P4 WT rats and plated in growth medium. $\boldsymbol{A}$, Transcription factor Olig2 (green) for oligodendroglia, adaptor protein 4 (red) and DAPI (blue) for nuclei. $\boldsymbol{B}$, Transcription factor Olig2 (red), autophagy protein ATG9A (red), and DAPI (blue).

verteporfin significantly reduced the number and length of myelin segments on neurons.

As mentioned previously, mTOR activity is closely associated with autophagy induction. Interestingly, mTOR activity is also associated with oligodendrocyte myelination in multiple contexts (for review, see Dello Russo et al., 2013; Figlia et al., 2018); and as reported by Dello Russo et al. (2013), maximal white matter mTOR activity has been identified in the postnatal rat brain during PFC myelination (Tyler et al., 2011). Similarly, these authors discovered that mTOR activity was necessary for oligodendrocyte differentiation in OPC-DRG cocultures (Tyler et al., 2009). Additional studies have found that tight regulation of the mTOR complex mTORC1 is necessary for oligodendrocyte myelination (Lebrun-Julien et al., 2014). mTOR signaling complexes were shown to modulate myelin genes at the mRNA level; therefore, the effects of mTOR signaling on oligodendrocyte development could occur through changes in autophagy or changes to myelin gene expression. The exact mechanisms underlying these relationships remain to be elucidated. The autophagy activator rapamycin and its cellular target mTOR have emerged as a potential therapeutic for experimental autoimmune encephalomyelitis and multiple sclerosis (Dello Russo et al., 2013). Given that mTOR is involved in multiple cell processes beyond autophagy, however, it is important when manipulating this pathway to distinguish direct effects on autophagy from an autophagic response to the manipulation of other signaling pathways.

In summary, the work discussed in this section shows a clear and well-regulated function of autophagy across oligodendrocyte development and maturation. The role of autophagy in oligoden- drocyte development is also suggested by the pathologies of various developmental white matter disorders. Clinical evidence suggests that autophagy plays an important role in childhood white matter development (Tyler et al., 2011; Ebrahimi-Fakhari et al., 2014, 2018), but more studies are needed to better understand this process and how it may be modulated or targeted as a therapeutic for developmental disorders.

\section{Traumatic injury and regeneration}

Schwann cell autophagy: mechanisms of myelin clearance following nerve lesion

During injury, a major role that Schwann cells perform is the phagocytosis of myelin debris. Recently, Schwann cell autophagymediated myelin clearance has been widely demonstrated (Gomez-Sanchez et al., 2015; Jang et al., 2015; Weiss et al., 2016; Brosius Lutz et al., 2017). In these studies, a selective autophagy termed "myelinophagy" was shown to drive myelin debris clearance following nerve injury (Gomez-Sanchez et al., 2015). Schwann cell-mediated myelin clearance was demonstrated with the findings of myelin debris inside Schwann cell autophagosomes and through elimination experiments that used pharmacological inhibition of autophagy and Atg7-KO animals to show that inhibition of autophagy significantly delays myelin breakdown after injury (Gomez-Sanchez et al., 2015). Further, Schwann cell specificity was demonstrated in animals with Schwann-cell-specific Atg7 KO, which exhibited delayed myelin clearance after Wallerian degeneration (Jang et al., 2016). Surprisingly, further investigations revealed that myelin clearance by macrophage cells is also decreased in these animals (Jang et al., 2017). Jang et al. (2017) proposed that Schwann cell autophagolysosome activity was required to provide the membrane remodeling necessary to allow macrophage cells access to myelin for digestion.

In addition to classical autophagic markers, autophagy is implicated in Schwann cell function during injury through studies of miRNA changes. Spinal nerve ligation increases total RNA levels of miR-195 in dorsal horn spinal cord sections from $2 \mathrm{~d}$ until $14 \mathrm{~d}$ after injury (Shi et al., 2013). miR-195 inhibition increases the LC3B-II:LC3B-I ratio, indicating increased autophagy, and the downstream target of miR-195 was determined to be ATG14 (Shi et al., 2013). Therefore, miR-195 was determined to be a negative regulator of autophagy in the spinal cord, and in cultured primary microglia (Shi et al., 2013). miR-195 expression was not analyzed in the white matter in this study; interestingly, however, miR-195 is upregulated in Schwann cells during myelination and significantly decreased in Schwann cells with defective and thin myelin (Bremer et al., 2010). Together, these data suggest that miR-195 acts in separate contexts to inhibit autophagy and promote maturation of Schwann cells. This relationship provides further evidence that autophagy is directly involved in Schwann cell development and consequent myelin architecture. Moreover, miR-195 may be a potential therapeutic target in spinal cord injury given its ability to affect both autophagy and myelin levels.

In addition to autophagy-mediated pathways, Schwann cells can also clear myelin using Axl- and Merk-receptor-mediated phagocytosis (Brosius Lutz et al., 2017). Axl and Merk are expressed by CNS astrocytes; therefore, it has been proposed that these receptors may present therapeutics and pharmacological targets to promote myelin clearance in the CNS (Brosius Lutz et al., 2017). Together, the studies reported here suggest that autophagy is a major physiological process that allows myelinating glia to meditate myelin debris clearance. 
Table 3. Pharmacological activators and inhibitors of autophagy

\begin{tabular}{ll}
\hline Activators & Mechanism \\
\hline Rapamycin & $\begin{array}{l}\text { Binds to the FKBP12 protein, forming a gain-of-function complex that works as an allosteric inhibitor of mTORC1 } \\
\text { (Sabatini et al., 1994) with consequent activation of autophagy }\end{array}$ \\
& \\
& Analog of rapamycin, induces inhibition of mTORC1 by forming complex with cytosolic FKBP12 (Gore et al., 2013) \\
Ridaforolimus & Targets one subunit of the vATPase, leading to the inhibition of mTORC1 (Chung et al., 2019) \\
EN6 & Autophagy inducing peptide, lipidates LC3B and increases p62 protein levels (Shoji-Kawata et al., 2013)
\end{tabular}

Inhibitors

Autophagy inducing peptide, lipidates LC3B and increases p62 protein levels (Shoji-Kawata et al., 2013)

Bankston et al. (2019)

3-Methyladenine

Inhibits PI3KC3 by binding the ATP-binding site, with consequent blockage of autophagosome formation

Gomez-Sanchez et al. (2015)

Chen et al. (2016)

Ko et al. (2018)

Marinelli et al. (2014)

Spautin- $1^{a}$

Promotes the degradation of PI3KC3 kinase complex by inhibiting two ubiquitin specific peptidases, USP10 and

Ohri et al. (2018) USP13, that target the Beclin1 subunit of the complex (Liu et al., 2011)

Bafilomycin A1 Inhibits autophagosomal/lysosomal membrane fusion, by targeting the vATPase

Gomez-Sanchez et al. (2015)

Wortmannin Inhibits PI3KC3 and suppressing PI3P production (Petiot et al., 2000)

$\mathrm{KU}_{55933^{a}} \quad$ Selective inhibitor of the VPS34 complex (Farkas et al., 2011)

Verteporfin $^{a} \quad$ Stimulates oligomerization of p62, preventing autophagosome closure (Donohue et al., 2011)

Docosahexaenoic acid Triggers p53 oxidative reduction, with consequent activation of AMPK/mTOR signaling (Jing et al., 2011)

Chen et al. (2016)

Bankston et al. (2019)

Bankston et al. (2019)

Yin et al. (2018)

${ }^{a}$ Directly affects autophagy.

Schwann cell autophagy: pharmacological manipulation of myelin clearance following nerve lesion

Pharmacological manipulation of autophagy has both enhanced and complicated understanding of Schwann cell autophagy following injury. The contributions of Schwann cell autophagy to recovery from PNS injury has been evaluated though a series of studies that activate autophagy. Autophagy is a major step in the injury process, as nerve cut was shown to increase autophagy-related mRNA transcripts and autophagy-related protein expression in injured nerve segments (Marinelli et al., 2014; Gomez-Sanchez et al., 2015; Huang et al., 2016; Jang et al., 2016). This involvement of autophagy in injury has been manipulated therapeutically. Promoting Schwann cell autophagy with rapamycin in the first week after mouse sciatic nerve injury produced anti-inflammatory effects and led to increased myelin compaction along the sciatic nerve (Marinelli et al., 2014). Rapamycin treatment after nerve injury also increased Schwann cell proliferation (Marinelli et al., 2014). It has also been reported that induction of autophagy in Schwann cells promotes nerve regeneration after injury (Huang et al., 2016). After Wallerian degeneration, inhibition of the proteasome limits Schwann cell expression of p75, a nerve growth factor receptor and marker of Schwann cell dedifferentiation. Dedifferentiation of Schwann cells is associated with peripheral axon demyelination (Kim et al., 2014).

Interestingly, inhibiting Schwann cell autophagy pharmacologically with 3-methyladenine or using a mouse haploinsufficient at the Ambral gene resulted in increased and prolonged neuropathic pain behavior after nerve injury (Marinelli et al., 2014). Furthermore, inhibition of autophagy after nerve damage is accompanied by increased neurofilament accumulation (Ko et al., 2018), suggesting that Schwann cell autophagy slows and ameliorates scar formation after injury.

As noted above, multiple pharmacological agents have been used to activate or inhibit autophagy; in particular, activation of autophagy is often stimulated by inhibitors of mTOR (e.g., rapamycin, or activators of AMPK), which subsequently inhibits mTOR. Since both mTOR and AMPK act as regulators for several cellular pathways, it is only with more specific drugs that pharmacological data can be fully interpreted. Some of the drugs used also have more than one target. For example, Wortmannin tar- gets PI3KC1/3, myosin light chain kinase, mTOR, and DNAdependent protein kinase (Kong and Yamori, 2008). We have summarized the pharmacological drugs most often used to manipulate autophagy pathway in Table 3, indicating which are specific for autophagy.

It is important to note that the language surrounding Schwann cell autophagy in relation to myelin clearance and architecture tends to polarize the literature. Some researchers state that Schwann cell autophagy is beneficial and facilitates necessary myelin debris clearance, whereas others claim that Schwann cell autophagy is harmful and causes unnecessary myelin degradation, eliminating myelin architecture. Importantly, half of the literature suggests that autophagy inhibitors would promote recovery after nervous system injury, whereas the other half recommends autophagy activators to promote functional recovery. Given that factors regulating the context and extent of myelin clearance are areas of active investigation, more research is required before autophagy modulators can be used to maximum benefit as a therapeutic target in recovery from CNS or PNS injury.

\section{Oligodendrocyte autophagy: inflammation, stroke, brain and spinal cord injury}

Although still incompletely understood, recent literature has made it clear that oligodendrocyte autophagy is involved in both CNS injury and recovery. Multiple studies have reported an increase in autophagy-related transcripts and proteins, including Atg5 and LC3B, 1 week after spinal cord injury (MuñozGaldeano et al., 2018; Ohri et al., 2018). Furthermore, genetic deletion of Atg5 in oligodendrocytes significantly impairs the extent of functional recovery, as measured by Basso Mouse Scale locomotor analysis 28-42 d after spinal cord injury (Ohri et al., 2018). In contrast, functional recovery was also more likely when ER homeostasis, as opposed to ER stress (an initiator of autophagy) (Yorimitsu et al., 2006; Ohri et al., 2018), was promoted (Ohri et al., 2011, 2013). Additionally, there was a reduction in the spared white matter of transverse histological section 6 weeks after spinal cord injury in animals in which Atg5 was genetically deleted, which was interpreted to represent decreased function recovery. In past studies, it has been argued that spared white 
matter is more predictive of functional recovery than neuronal loss, specifically for thoracic contusions (Ohri et al., 2018). Therefore, decreased spared white matter in the $A \operatorname{tg} 5^{-1-}$ tissue suggests that active autophagy may contribute to the maintenance and protection of myelin after injury.

Altered oligodendrocyte autophagy has been also associated with additional types of injury, including inflammation, traumatic brain injury (TBI), and stroke (Zhang and Wang, 2018). Following white matter injury, pattern-recognition Toll-like receptors TLR3 and TLR4 has been shown to induce autophagy, and TLR3 was found to colocalize with the autophagosome (Vontell et al., 2015). This demonstrates that, within the brain parenchyma, white matter injury induces autophagosome formation. Autophagy inhibitor docosahexaenoic acid, when given immediately following a TBI, was shown to limit the extent of both white matter and gray matter injury in the hippocampus and cortex (Yin et al., 2018). The protection of gray and white matter was correlated with improved Morris water maze performance in docosahexaenoic acid-treated versus nontreated animals (Yin et al., 2018). These recent advances highlight the therapeutic potential that targeting autophagy may provide to improve TBI treatment.

Ischemic stroke is a sudden loss of glucose and oxygen, and this often causes extensive damage to white matter (Wang et al., 2016). Given that autophagy is induced by hypoxia, growth factor withdrawal, and glucose starvation (Dikic and Elazar, 2018), autophagic activity in oligodendrocytes after ischemic stroke would seem an important contributor to white matter injury and functional recovery. Given the recent success of autophagy inhibitors in treating TBI, autophagy seems a promising therapeutic target to treat damage from stroke.

\section{Autophagy contributions to neurological disorders CNS myelin disorders}

Abnormal autophagy flux is associated with dozens of neurological disorders that have myelin abnormalities as a hallmark feature, presenting an important contributor and therapeutic target for these diseases (Eskelinen and Saftig, 2009; Jiang and Mizushima, 2014; Menzies et al., 2015; Levine and Kroemer, 2019). Diseases with additional myelin phenotypes and autophagic dysfunction include amyotrophic lateral sclerosis (Rubino et al., 2012; Hirano et al., 2013), Alzheimer's disease (Li et al., 2010; Zare-Shahabadi et al., 2015; Uddin et al., 2018), frontotemporal dementia/degeneration (Rubino et al., 2012), hereditary spastic paraplegias (Winner et al., 2004; Olmez et al., 2006; Al-Yahyaee et al., 2006; Oz-Levi et al., 2012), multiple sclerosis (Liang and Le, 2015; Igci et al., 2016; Patergnani et al., 2018), Nasu-Hakola disease (Satoh et al., 2014), and Parkinson's disease (Gan-Or et al., 2015). More research is needed to elucidate the relationship between autophagy and lifelong myelin development, plasticity, and maintenance in association with neurological disease.

Hereditary spastic paraplegia (HSP) is a rare genetic disorder, with dozens of genetic subtypes, that presents in childhood and leads to progressive lower-limb paralysis and spasticity (Gould and Brady, 2004; Fink, 2013). A large portion of the $>70$ genes linked to HSPs are involved in the autophagy pathway, axon transport, ER, or mitochondrial stress (Fink, 2013), and a large subset of HSP cases are known as a "disease of autophagy." A thin corpus callosum is frequently reported in patients with HSP (Winner et al., 2004; Al-Yahyaee et al., 2006; Olmez et al., 2006; Ebrahimi-Fakhari et al., 2018) and in animal models of HSP (De Pace et al., 2018). Because HSP is both a developmental and degenerative disorder with symptoms that can present at any age
(Fink, 2013), HSP pathology suggests a crucial role of autophagy in CNS and PNS white matter development and maintenance.

One of the proteins affected in HSP is adaptor protein 4 (AP4), which exports ATG9A from the Golgi to preautophagosomes (Hirst et al., 2013; Mattera et al., 2017; Roubertie et al., 2018) (Fig. 1). The relationship between AP-4 and ATG9A is an interesting one because AP-4 is linked to abnormal myelination in HSP (Ebrahimi-Fakhari et al., 2018) and ATG9A mRNA levels are reported to be significantly reduced in blood samples from patients with the classical demyelinating disorder multiple sclerosis (Igci et al., 2016). LC3B, the marker of active autophagy, was not, however, identified in oligodendrocytes surviving multiple sclerosis lesions when analyzed in postmortem brains (Satoh et al., 2014). Autophagy activation has been reported in additional types of demyelinated lesions. Autophagy marker LC3B was found to be highly expressed in surviving oligodendrocytes located in demyelinated lesions of postmortem brains with NasuHakola disease, a rare genetic disorder hallmarked by sclerosing demyelinating regions (Satoh et al., 2014). Together, these studies present intriguing but complex evidence for the involvement of autophagy in both developmental and neurodegenerative CNS dysmyelinating disorders.

Leukoencephalopathy with vanishing white matter is a genetically heterogeneous collection of white matter disorders that can vary in childhood-, adolescent-, or adult-onset stages (Bugiani et al., 2010). Canonically, leukoencephalopathy is associated with mutations to eukaryotic translation initiation factor 2 (eIF2B) subunits 1-5 (Bugiani et al., 2010; Matsukawa et al., 2011; Schiffmann et al., 2012). In oligodendrocytes with a mutant version of eIF2B, autophagic flux was slowed and tolerance to ER stress was significantly diminished (Chen et al., 2016). In a different genetic subtype of leukoencephalopathy, researchers found that mutations to the Vps11 gene, which encodes the vacuolar protein sorting-associated protein 11 (VPS11), was present (Zhang et al., 2016). When expressed in zebrafish, the gene mutation led to progressive myelin loss and elevated levels of LC3B and p62, markers of elevated autophagy and autophagy dysfunction, respectively (Zhang et al., 2016). The link between the dysregulated autophagy and abnormal myelin phenotypes is not causally tested in this study, but the findings provide an important avenue for new research.

Disruption of autophagy in nonmyelinating cells can also affect white matter structure. For example, pathology of Alexander's disease has been linked with autophagic dysregulation, and accumulation of GFAP protein in white matter astrocytes (Brenner et al., 2001; Hagemann et al., 2006; Tanaka et al., 2007). High levels of oxidative stress in the corpus callosum have also been observed in a mouse model of Alexander's disease (Hagemann et al., 2006). Further, the pathology of Alexander's disease highlights that, despite often being used interchangeably, myelinating glia, myelin architecture, and white matter each have independent biologies and each may require different types of inquiry or therapeutic strategies.

\section{PNS myelin disorders}

In addition to the well-documented role that autophagy in myelinating glia plays in diseases of the CNS, emerging evidence suggests contributions of autophagy to the pathogenesis of several PNS demyelinating diseases. In Charcot-Marie-Tooth disease type 1A (CMT1A), a peripheral demyelinating disorder, multiple groups have found evidence of dysregulated autophagy in Schwann cells (Hutton et al., 2011; Hantke et al., 2014; Lee et al., 2018). For example, elevated c-Jun levels, an activator of au- 
tophagy, were reported in Schwann cells of a CMT1A animal model (Hutton et al., 2011; Hantke et al., 2014). Additionally, increased LC3B-II levels and autophagosome counts have been reported in CMT1A-patient-derived Schwann cells (Lee et al., 2018). In a similar disorder, Charcot-Marie-Tooth disease Type 4J (CMT4J), a mutation in the protein FIG4, results in Schwann cell demyelination and decreased autophagy-mediated myelin clearance (Vaccari et al., 2015). The authors highlight the necessity of endosomal trafficking, which is a feature of autophagic flux, in Schwann cells for myelin maintenance.

In an animal model for the PNS disease chronic inflammatory demyelinating polyradiculoneuropathy, researchers have identified significantly decreased colocalization of MAP1LC3B- and S100-positive Schwann cells in the sciatic nerve of chronic inflammatory demyelinating polyradiculoneuropathy animals (Brun et al., 2017). In a different animal model of inflammatory demyelination, B7-2-deficient NOD mice, autophagy-associated proteins LC3B and LAMP1 were also identified in Schwann cells during Wallerian degeneration (Jang et al., 2015). The authors conclude that autophagy is active in Schwann cells during inflammatory peripheral demyelination disorders. Autophagy has been also implicated in the demyelinating PNS disorder Guillain-Barré syndrome (Muller et al., 2017; Brun et al., 2017); however, current studies have not determined whether the autophagy abnormalities are specific to the white matter. It is important to note that, similar to the literature on Schwann cell autophagy in injury and repair, it is unclear in the PNS disease literature whether Schwann cell autophagy is a sign of productive physiological recovery or pathological harm. This question surrounding the role of autophagy in myelin-based disease and repair remains an important and highly debated area for future research.

In conclusion, given the close association with myelin repair and recovery after injury, autophagy is a critical, and at present overlooked, component of myelinating glial function and plasticity. Targeting autophagy in myelinating glia presents a potential new direction for disease and injury treatments, and such research will ultimately unveil fundamental underlying biology regulating the development and plasticity of the nervous system.

\section{References}

Al-Yahyaee S, Al-Gazali LI, De Jonghe P, Al-Barwany H, Al-Kindi M, De Vriendt E, Chand P, Koul R, Jacob PC, Gururaj A, Sztriha L, Parrado A, Van Broeckhoven C, Bayoumi RA (2006) A novel locus for hereditary spastic paraplegia with thin corpus callosum and epilepsy. Neurology 66:1230-1234.

Axe EL, Walker SA, Manifava M, Chandra P, Roderick HL, Habermann A, Griffiths G, Ktistakis NT (2008) Autophagosome formation from compartments enriched in phosphatidylinositol 3-phosphate and dynamically connected to the endoplasmic reticulum. J Cell Biol 182:685-701.

Bahrami AH, Lin MG, Ren X, Hurley JH, Hummer G (2017) Scaffolding the cup-shaped double membrane in autophagy. PLoS Comput Biol 13: e1005817.

Bankston AN, Forston MD, Howard RM, Andres KR, Smith AE, Ohri SS, Bates ML, Bunge MB, Whittemore SR (2019) Autophagy is essential for oligodendrocyte differentiation, survival, and proper myelination. Glia 67:1745-1759.

Birgisdottir ÅB, Lamark T, Johansen T (2013) The LIR motif: crucial for selective autophagy. J Cell Sci 126:3237-3247.

Boland B, Kumar A, Lee S, Platt FM, Wegiel J, Yu WH, Nixon RA (2008) Autophagy induction and autophagosome clearance in neurons: relationship to autophagic pathology in Alzheimer's disease. J Neurosci 28:69266937.

Bremer J, O'Connor T, Tiberi C, Rehrauer H, Weis J, Aguzzi A (2010) Ablation of Dicer from murine Schwann cells increases their proliferation while blocking myelination. PLoS One 5:e12450.

Brenner M, Johnson AB, Boespflug-Tanguy O, Rodriguez D, Goldman JE,
Messing A (2001) Mutations in GFAP, encoding glial fibrillary acidic protein, are associated with Alexander disease. Nat Genet 27:117-120.

Brosius Lutz AB, Chung WS, Sloan SA, Carson GA, Zhou L, Lovelett E, Posada S, Zuchero JB, Barres BA (2017) Schwann cells use TAM receptor-mediated phagocytosis in addition to autophagy to clear myelin in a mouse model of nerve injury. Proc Natl Acad Sci U S A 114: E8072-E8080.

Brun S, Schall N, Jeltsch-David H, Sèze J, Muller S (2017) Assessing autophagy in sciatic nerves of a rat model that develops inflammatory autoimmune peripheral neuropathies. Cells 6:30.

Bugiani M, Boor I, Powers JM, Scheper GC, van der Knaap MS (2010) Leukoencephalopathy with vanishing white matter: a review. J Neuropathol Exp Neurol 69:987-996.

Chen N, Dai L, Jiang Y, Wang J, Hao H, Ren Y, Leng X, Zang L, Wu Y (2016) Endoplasmic reticulum stress intolerance in EIF2B3 mutant oligodendrocytes is modulated by depressed autophagy. Brain Dev 38:507-515.

Chung CY, Shin HR, Berdan CA, Ford B, Ward CC, Olzmann JA, Zoncu R, Nomura DK (2019) Covalent targeting of the vacuolar $\mathrm{H}^{+}$-ATPase activates autophagy via mTORC1 inhibition. Nat Chem Biol 15:776-785.

De Duve C, Wattiaux R (1966) Functions of lysosomes. Annu Rev Physiol 28:435-492.

Dello Russo C, Lisi L, Feinstein DL, Navarra P (2013) mTOR kinase, a key player in the regulation of glial functions: relevance for the therapy of multiple sclerosis. Glia 61:301-311.

De Pace R, Skirzewski M, Damme M, Mattera R, Mercurio J, Foster AM, Cuitino L, Jarnik M, Hoffmann V, Morris HD, Han TU, Mancini GM, Buonanno A, Bonifacino JS (2018) Altered distribution of ATG9A and accumulation of axonal aggregates in neurons from a mouse model of AP-4 deficiency syndrome. PLoS Genet 14:e1007363.

Dice JF (1990) Peptide sequences that target cytosolic proteins for lysosomal proteolysis. Trends Biochem Sci 15:305-309.

Dikic I, Elazar Z (2018) Mechanism and medical implications of mammalian autophagy. Nat Rev Mol Cell Biol 19:349-364.

Donohue E, Tovey A, Vogl AW, Arns S, Sternberg E, Young RN, Roberge M (2011) Inhibition of autophagosome formation by the benzoporphyrin derivative verteporfin. J Biol Chem 286:7290-7300.

Dunlop EA, Tee AR (2014) mTOR and autophagy: a dynamic relationship governed by nutrients and energy. Semin Cell Dev Biol 36:121-129.

Dutta DJ, Woo DH, Lee PR, Pajevic S, Bukalo O, Huffman WC, Wake H, Basser PJ, SheikhBahaei S, Lazarevic V, Smith JC, Fields RD (2018) Regulation of myelin structure and conduction velocity by perinodal astrocytes. Proc Natl Acad Sci U S A 115:11832-11837.

Ebrahimi-Fakhari D, Wahlster L, Hoffmann GF, Kölker S (2014) Emerging role of autophagy in pediatric neurodegenerative and neurometabolic diseases. Pediatr Res 75:217-226.

Ebrahimi-Fakhari D, Behne R, Davies AK, Hirst J (2018) AP-4-associated hereditary spastic paraplegia. In: GeneReviews (Adam MP, Ardinger HH, Pagon RA, et al., eds). Seattle: University of Washington.

Eskelinen EL, Saftig P (2009) Autophagy: a lysosomal degradation pathway with a central role in health and disease. Biochim Biophys Acta 1793: $664-673$.

Farkas T, Daugaard M, Jäättelä M (2011) Identification of small molecule inhibitors of phosphatidylinositol 3-kinase and autophagy. J Biol Chem 286:38904-38912.

Figlia G, Gerber D, Suter U (2018) Myelination and mTOR. Glia 66: 693-707.

Fimia GM, Stoykova A, Romagnoli A, Giunta L, Di Bartolomeo S, Nardacci R, Corazzari M, Fuoco C, Ucar A, Schwartz P, Gruss P, Piacentini M, Chowdhury K, Cecconi F (2007) Ambral regulates autophagy and development of the nervous system. Nature 447:1121-1125.

Fink JK (2013) Hereditary spastic paraplegia: clinico-pathologic features and emerging molecular mechanisms. Acta Neuropathol 126:307-328.

Galluzzi L, Pietrocola F, Bravo-San Pedro JM, Amaravadi RK, Baehrecke EH, Cecconi F, Codogno P, Debnath J, Gewirtz DA, Karantza V, Kimmelman A, Kumar S, Levine B, Maiuri MC, Martin SJ, Penninger J, Piacentini M, Rubinsztein DC, Simon HU, Simonsen A, et al. (2015) Autophagy in malignant transformation and cancer progression. EMBO J 34:856-880.

Ganley IG, Lam du H, Wang J, Ding X, Chen S, Jiang X (2009) ULK1.ATG13.FIP200 complex mediates mTOR signaling and is essential for autophagy. J Biol Chem 284:12297-12305.

Gan-Or Z, Dion PA, Rouleau GA (2015) Genetic perspective on the role of 
the autophagy-lysosome pathway in Parkinson disease. Autophagy 11:1443-1457.

Geng J, Nair U, Yasumura-Yorimitsu K, Klionsky DJ (2010) Post-Golgi Sec proteins are required for autophagy in Saccharomyces cerevisiae. Mol Biol Cell 21:2257-2269.

Glick D, Barth S, Macleod KF (2010) Autophagy: cellular and molecular mechanisms. J Pathol 221:3-12.

Gomes LC, Dikic I (2014) Autophagy in antimicrobial immunity. Mol Cell $54: 224-233$

Gomez-Sanchez JA, Carty L, Iruarrizaga-Lejarreta M, Palomo-Irigoyen M, Varela-Rey M, Griffith M, Hantke J, Macias-Camara N, Azkargorta M, Aurrekoetxea I, De Juan VG, Jefferies HB, Aspichueta P, Elortza F, Aransay AM, Martínex-Chantar ML, Baas F, Mato JM, Mirsky R, Woodhoo A, et al. (2015) Schwann cell autophagy, myelinophagy, initiates myelin clearance from injured nerves. J Cell Biol 210:153-168.

Gore L, Tippett TM, Katzenstein HM, Boklan J, Narendran A, Smith A, Macy ME, Rolla K, Narashimhan N, Squillace RM, Turner CD, Haluska FG, Nieder M (2013) A multicenter, first-in-pediatrics, Phase 1, pharmacokinetic and pharmacodynamic study of ridaforolimus in patients with refractory solid tomors. Clinical Cancer Research 19:3649-3658.

Gould RM, Brady ST (2004) Neuropathology: many paths lead to hereditary spastic paraplegia. Curr Biol 14:R903-R904.

Hagemann TL, Connor JX, Messing A (2006) Alexander disease-associated glial fibrillary acidic protein mutations in mice induce Rosenthal fiber formation and a white matter stress response. J Neurosci 26:11162-11173.

Hailey DW, Rambold AS, Satpute-Krishnan P, Mitra K, Sougrat R, Kim PK, Lippincott-Schwartz J (2010) Mitochondria supply membranes for autophagosome biogenesis during starvation. Cell 141:656-667.

Hantke J, Carty L, Wagstaff LJ, Turmaine M, Wilton DK, Quintes S, Koltzenburg M, Baas F, Mirsky R, Jessen KR (2014) c-jun activation in Schwann cells protects against loss of sensory axons in inherited neuropathy. Brain 137:2922-2937.

Hara T, Takamura A, Kishi C, Iemura S, Natsume T, Guan JL, Mizushima N (2008) FIP200, a ULK-interacting protein, is required for autophagosome formation in mammalian cells. J Cell Biol 181:497-510.

Hirano M, Nakamura Y, Saigoh K, Sakamoto H, Ueno S, Isono C, Miyamoto K, Akamatsu M, Mitsui Y, Kusunoki S (2013) Mutations in the gene encoding p62 in Japanese patients with amyotrophic lateral sclerosis. Neurology 80:458-463.

Hirst J, Irving C, Borner GH (2013) Adaptor protein complexes AP-4 and AP-5: new players in endosomal trafficking and progressive spastic paraplegia. Traffic 14:153-164.

Hosokawa N, Hara T, Kaizuka T, Kishi C, Takamura A, Miura Y, Iemura S, Natsume T, Takehana K, Yamada N, Guan JL, Oshiro N, Mizushima N (2009) Nutrient-dependent mTORC1 association with the ULK1Atg13-FIP200 complex required for autophagy. Mol Biol Cell 20: 1981-1991

Huang HC, Chen L, Zhang HX, Li SF, Liu P, Zhao TY, Li CX (2016) Autophagy promotes peripheral nerve regeneration and motor recovery following sciatic nerve crush injury in rats. J Mol Neurosci 58:416-423.

Hutton EJ, Carty L, Laurá M, Houlden H, Lunn MP, Brandner S, Mirsky R, Jessen K,Reilly MM (2011) c-jun expression in human neuropathies: a pilot study. J Peripher Nerv Syst 16:295-303.

Igci M, Baysan M, Yigiter R, Ulasli M, Geyik S, Bayraktar R, Bozgeyik I, Bozgeyik E, Bayram A, Cakmak EA (2016) Gene expression profiles of autophagy-related genes in multiple sclerosis. Gene 588:38-46.

Itakura E, Kishi-Itakura C, Mizushima N (2012) The hairpin-type tailanchored SNARE syntaxin 17 targets to autophagosomes for fusion with endosomes/lysosomes. Cell 151:1256-1269.

Jang SY, Shin YK, Park SY, Park JY, Rha SH, Kim JK, Lee HJ, Park HT (2015) Autophagy is involved in the reduction of myelinating Schwann cell cytoplasm during myelin maturation of the peripheral nerve. PLoS One 10:e0116624.

Jang SY, Shin YK, Park SY, Park JY, Lee HJ, Yoo YH, Kim JK, Park HT (2016) Autophagic myelin destruction by Schwann cells during Wallerian degeneration and segmental demyelination. Glia 64:730-742.

Jang SY, Yoon BA, Shin YK, Yun SH, Jo YR, Choi YY, Ahn M, Shin T, Park JI, Kim JK, Park HT (2017) Schwann cell dedifferentiation-associated demyelination leads to exocytotic myelin clearance in inflammatory segmental demyelination. Glia 65:1848-1862.

Jean S, Kiger AA (2014) Classes of phosphoinositide 3-kinases at a glance. J Cell Sci 127:923-928.
Jia R, Guardia CM, Pu J, Chen Y, Bonifacino JS (2017) BORC coordinates encounter and fusion of lysosomes with autophagosomes. Autophagy 13:1648-1663.

Jiang P, Mizushima N (2014) Autophagy and human diseases. Cell Res 24:69-79.

Jing K, Song KS, Shin S, Kim N, Jeong S, Oh HR, Park JH, Seo KS, Heo JY, Han J, Park JI, Han C, Wu T, Kweon GR, Park SK, Yoon WH, Hwang BD, Lim K (2011) Docosahexaenoic acid induces autophagy through p53/ AMPK/mTOR signaling and promotes apoptosis in human cancer cells harboring wild-type p53. Autophagy 7:1348-1358.

Jung CH, Ro SH, Cao J, Otto NM, Kim DH (2010) mTOR regulation of autophagy. FEBS Lett 584:1287-1295.

Kim JK, Lee HJ, Park HT (2014) Two faces of Schwann cell dedifferentiation in peripheral neurodegenerative diseases: pro-demyelinating and axonpreservative functions. Neural Regen Res 9:19521954.

Kim J, Kundu M, Viollet B, Guan KL (2011) AMPK and mTOR regulate autophagy through direct phosphorylation of Ulk1. Nat Cell Biol 13:132-141.

Kimura S, Noda T, Yoshimori T (2007) Dissection of the autophagosome maturation process by a novel reporter protein, tandem fluorescenttagged LC3. Autophagy 3:452-460.

Klionsky DJ, Abdalla FC, Abeliovich H, Abraham RT, Acevedo-Arozena A, Adeli K, Agholme L, Agnello M, Agostinis P, Aguirre-Ghiso JA, Ahn HJ, Ait-Mohamed O, Ait-Si-Ali S, Akematsu T, Akira S, Al-Younes HM, AlZeer MA, Albert ML, Albin RL, Alegre-Abarrategui J, et al. (2012) Guidelines for the use and interpretation of assays for monitoring autophagy. Autophagy 8:445-544.

Ko PY, Yang CC, Kuo YL, Su FC, Hsu TI, Tu YK, Jou IM (2018) Schwanncell autophagy, functional recovery, and scar reduction after peripheral nerve repair. J Mol Neurosci 64:601-610.

Komatsu M, Wang QJ, Holstein GR, Friedrich VL Jr, Iwata J, Kominami E, Chait BT, Tanaka K, Yue Z (2007) Essential role for autophagy protein Atg7 in the maintenance of axonal homeostasis and the prevention of axonal degeneration. Proc Natl Acad Sci U S A 104:14489-14494.

Kong D, Yamori T (2008) Phosphatidylinositol 3-kinase inhibitors: promising drug candidates for cancer therapy. Cancer Sci 99:1734-1740.

Kuma A, Matsui M, Mizushima N (2007) LC3, an autophagosome marker, can be incorporated into protein aggregates independent of autophagy: caution in the interpretation of LC3 localization. Autophagy 3:323-328.

Kuma A, Komatsu M, Mizushima N (2017) Autophagy-monitoring and autophagy-deficient mice. Autophagy 13:1619-1628.

Lamb CA, Yoshimori T, Tooze SA (2013) The autophagosome: origins unknown, biogenesis complex. Nat Rev Mol Cell Biol 14:759-774.

Lebrun-Julien F, Bachmann L, Norrmén C, Trötzmüller M, Köfeler H, Rüegg MA, Hall MN, Suter U (2014) Balanced mTORC1 activity in oligodendrocytes is required for accurate CNS myelination. J Neurosci 34: 8432-8448.

Lee JA (2012) Neuronal autophagy: a housekeeper or a fighter in neuronal cell survival. Exp Neurobiol 21:1-8.

Lee S, Bazick H, Chittoor-Vinod V, Al Salihi MO, Xia G, Notterpek L (2018) Elevated peripheral myelin protein 22, reduced mitotic potential, and proteasome impairment in dermal fibroblasts from Charcot-MarieTooth disease type 1A patients. Am J Pathol 188:728-738.

Levine B, Klionsky DJ (2004) Development by self-digestion: molecular mechanisms and biological functions of autophagy. Dev Cell 6:463-477.

Levine B, Kroemer G (2019) Biological functions of autophagy genes: a disease perspective. Cell 176:11-42.

Li L, Zhang X, Le W (2010) Autophagy dysfunction in Alzheimer's disease. Neurodegener Dis 7:265-271.

Liang P, Le W (2015) Role of autophagy in the pathogenesis of multiple sclerosis. Neurosci Bull 31:435-444.

Li WW, Li J, Bao JK (2012) Microautophagy: lesser-known self-eating. Cell Mol Life Sci 69:1125-1136.

Liu J, Xia H, Kim M, Xu L, Li Y, Zhang L, Cai Y, Norberg HV, Zhang T, Furuya T, Jin M, Zhu Z, Wang H, Yu J, Li Y, Hao Y, Choi A, Ke H, Ma D, Yuan J (2011) Beclin 1 controls the levels of p53 by regulating the deubiquitination activity of USP10 and USP13. Cell 147:223-234.

Maday S, Holzbaur EL (2016) Compartment-specific regulation of autophagy in primary neurons. J Neurosci 36:5933-5945.

Mari M, Griffith J, Rieter E, Krishnappa L, Klionsky DJ, Reggiori F (2010) An Atg9-containing compartment that functions in the early steps of autophagosome biogenesis. J Cell Biol 190:1005-1022. 
Marinelli S, Nazio F, Tinari A, Ciarlo L, D’Amelio M, Pieroni L, Vacca V, Urbani A, Cecconi F, Malorni W, Pavone F (2014) Schwann cell autophagy counteracts the onset and chronification of neuropathic pain. Pain 155:93-107.

Marzella L, Ahlberg J, Glaumann H (1981) Autophagy, heterophagy, microautophagy and crinophagy as the means for intracellular degradation. Virchows Arch B Cell Pathol Incl Mol Pathol 36:219-234.

Matsukawa T, Wang X, Liu R, Wortham NC, Onuki Y, Kubota A, Hida A, Kowa H, Fukuda Y, Ishiura H, Mitsui J, Takahashi Y, Aoki S, Takizawa S, Shimizu J, Goto J, Proud CG, Tsuji S (2011) Adult-onset leukoencephalopathies with vanishing white matter with novel missense mutations in EIF2B2, EIF2B3, and EIF2B5. Neurogenetics 12:259-261.

Mattera R, Park SY, De Pace R, Guardia CM, Bonifacino JS (2017) AP-4 mediates export of ATG9A from the trans-Golgi network to promote autophagosome formation. Proc Natl Acad Sci U S A 114:E10697E10706.

Menzies FM, Fleming A, Rubinsztein DC (2015) Compromised autophagy and neurodegenerative diseases. Nat Rev Neurosci 16:345-357.

Menzies FM, Fleming A, Caricasole A, Bento CF, Andrews SP, Ashkenazi A, Füllgrabe J, Jackson A, Jimenez Sanchez M, Karabiyik C, Licitra F, Lopez Ramirez A, Pavel M, Puri C, Renna M, Ricketts T, Schlotawa L, Vicinanza M, Won H, Zhu Y, et al. (2017) Autophagy and neurodegeneration: pathogenic mechanisms and therapeutic opportunities. Neuron 93: $1015-1034$.

Mijaljica D, Devenish RJ (2013) Nucleophagy at a glance. J Cell Sci 126: $4325-4330$

Mitra S, Tsvetkov AS, Finkbeiner S (2009) Protein turnover and inclusion body formation. Autophagy 5:1037-1038.

Mizushima N, Komatsu M (2011) Autophagy: renovation of cells and tissues. Cell 147:728-741.

Mizushima N, Yamamoto A, Matsui M, Yoshimori T, Ohsumi Y (2004) In vivo analysis of autophagy in response to nutrient starvation using transgenic mice expressing a fluorescent autophagosome marker. Mol Biol Cell 15:1101-1111.

Muller S, Brun S, René F, de Sèze J, Loeffler JP, Jeltsch-David H (2017) Autophagy in neuroinflammatory diseases. Autoimmun Rev 16:856-874.

Muñoz-Galdeano T, Reigada D, Del Águila Á, Velez I, Caballero-López MJ, Maza RM, Nieto-Díaz M (2018) Cell specific changes of autophagy in a mouse model of contusive spinal cord injury. Front Cell Neurosci 12:164.

Ohashi Y, Munro S (2010) Membrane delivery to the yeast autophagosome from the Golgi-endosomal system. Mol Biol Cell 21:3998-4008.

Ohri S, Maddie MA, Zhao Y, Qiu MS, Hetman M, Whittemore SR (2011) Attenuating the endoplasmic reticulum stress response improves functional recovery after spinal cord injury. Glia 59:1489-1502.

Ohri S, Hetman M, Whittemore SR (2013) Restoring endoplasmic reticulum homeostasis improves functional recovery after spinal cord injury. Neurobiol Dis 58:29-37.

Ohri S, Bankston AN, Mullins SA, Liu Y, Andres KR, Beare JE, Howard RM, Burke DA, Riegler AS, Smith AE, Hetman M, Whittemore SR (2018) Blocking autophagy in oligodendrocytes limits functional recovery after spinal cord injury. J Neurosci 38:5900-5912.

Olmez A, Uyanik G, Ozgül RK, Gross C, Cirak S, Elibol B, Anlar B, Winner B, Hehr U, Topaloglu H, Winkler J (2006) Further clinical and genetic characterization of SPG11: hereditary spastic paraplegia with thin corpus callosum. Neuropediatrics 37:59-66.

Orsi A, Razi M, Dooley HC, Robinson D, Weston AE, Collinson LM, Tooze SA (2012) Dynamic and transient interactions of Atg9 with autophagosomes, but not membrane integration, is required for autophagy. Mol Biol Cell 23:1860-1873.

Oz-Levi D, Ben-Zeev B, Ruzzo EK, Hitomi Y, Gelman A, Pelak K, Anikster Y, Reznik-Wolf H, Bar-Joseph I, Olender T, Alkelai A, Weiss M, Ben-Asher E, Ge D, Shianna KV, Elazar Z, Goldstein DB, Pras E, Lancet D (2012) Mutation in TECPR2 reveals a role for autophagy in hereditary spastic paraparesis. Am J Hum Genet 91:1065-1072.

Pankiv S, Clausen TH, Lamark T, Brech A, Bruun JA, Outzen H, Øvervatn A, Bjørkøy G, Johansen T (2007) p62/SQSTM1 binds directly to Atg8/LC3 to facilitate degradation of ubiquitinated protein aggregates by autophagy. J Biol Chem 282:24131-24145.

Patergnani S, Castellazzi M, Bonora M, Marchi S, Casetta I, Pugliatti M, Giorgi C, Granieri E, Pinton P (2018) Autophagy and mitophagy elements are increased in body fluids of multiple sclerosis-affected individuals. J Neurol Neurosurg Psychiatry 89:439-441.
Pengo N, Agrotis A, Prak K, Jones J, Ketteler R (2017) A reversible phosphoswitch mediated by ULK1 regulates the activity of autophagy protease ATG4B. Nat Comm 8:294.

Petiot A, Ogier-Denis E, Blommaart EF, Meijer AJ, Codogno P (2000) Distinct classes of phosphatidylinositol $3^{\prime}$-kinases are involved in signaling pathways that control macroautophagy in HT-29 cells. J Biol Chem 275:992-998.

Pyo JO, Yoo SM, Ahn HH, Nah J, Hong SH, Kam TI, Jung S, Jung YK (2013) Overexpression of Atg5 in mice activates autophagy and extends lifespan. Nat Commun 4:2300.

Ravikumar B, Moreau K, Jahreiss L, Puri C, Rubinsztein DC (2010) Plasma membrane contributes to the formation of pre-autophagosomal structures. Nat Cell Biol 12:747-757.

Roubertie A, Hieu N, Roux CJ, Leboucq N, Manes G, Charif M, Echenne B, Goizet C, Guissart C, Meyer P, Marelli C, Rivier F, Burglen L, Horvath R, Hamel CP, Lenaers G (2018) AP4 deficiency: a novel form of neurodegeneration with brain iron accumulation?. Neurol Genet 4:e217.

Rubino E, Rainero I, Chiò A, Rogaeva E, Galimberti D, Fenoglio P, Grinberg Y, Isaia G, Calvo A, Gentile S, Bruni AC, St George-Hyslop PH, Scarpini E, Gallone S, Pinessi L (2012) SQSTM1 mutations in frontotemporal lobar degeneration and amyotrophic lateral sclerosis. Neurology 79:15561562 .

Russell RC, Ye Tian Y, Yuan H, Park HW, Chang YY, Kim J, Kim H, Neufeld TP, Dillin A, Guan KL (2013) ULK1 induces autophagy by phosphorylating beclin-1 and activating VPS34 lipid kinase. Nat Cell Biol 15:741750.

Sabatini DM, Erdjument-Bromage H, Lui M, Tempst P, Snyder SH (1994) RAFT1: a mammalian protein that binds to FKBP12 in a rapamycindependent fashion and is homologous to yeast TORs. Cell 78:35-43.

Sahu R, Kaushik S, Clement CC, Cannizzo ES, Scharf B, Follenzi A, Potolicchio I, Nieves E, Cuervo AM, Santambrogio L (2011) Microautophagy of cytosolic proteins by late endosomes. Dev Cell 20:131-139.

Satoh J, Motohashi N, Kino Y, Ishida T, Yagishita S, Jinnai K, Arai N, Nakamagoe K, Tamaoka A, Saito Y, Arima K (2014) LC3, an autophagosome marker, is expressed on oligodendrocytes in Nasu-Hakola disease brains. Orphanet J Rare Dis 9:68.

Schiffmann R, Fogli A, Van der Knaap MS, Boespflug-Tanguy O (2012) Childhood ataxia with central nervous system hypomyelination/vanishing white matter. In: GeneReviews (Adam MP, Ardinger HH, Pagon RA, et al., eds), pp 1993-2019. Seattle: University of Washington.

Semenza GL (2010) HIF-1: upstream and downstream of cancer metabolism. Curr Opin Genet Dev 20:51-56.

Shaid S, Brandts CH, Serve H, Dikic I (2013) Ubiquitination and selective autophagy. Cell Death Differ 20:21-30.

Shi G, Shi J, Liu K, Liu N, Wang Y, Fu Z, Ding J, Jia L, Yuan W (2013) Increased miR-195 aggravates neuropathic pain by inhibiting autophagy following peripheral nerve injury. Glia 61:504-512.

Shoji-Kawata S, Sumpter R, Leveno M, Campbell GR, Zou Z, Kinch L, Wilkins AD, Sun Q, Pallauf K, MacDuff D, Huerta C, Virgin HW, Helms JB, Eerland R, Tooze SA, Xavier R, Lenschow DJ, Yamamoto A, King D, Lichtarge $\mathrm{O}$, et al. (2013) Identification of a candidate therapeutic autophagy-inducing peptide. Nature 494:201-206.

Stolz A, Ernst A, Dikic I (2014) Cargo recognition and trafficking in selective autophagy. Nat Cell Biol 16:495-501.

Tanaka KF, Takebayashi H, Yamazaki Y, Ono K, Naruse M, Iwasato T, Itohara S, Kato H, Ikenaka K (2007) Murine model of Alexander disease: analysis of GFAP aggregate formation and its pathological significance. Glia 55:617-631.

Tyler WA, Gangoli N, Gokina P, Kim HA, Covey M, Levison SW, Wood TL (2009) Activation of the mammalian target of rapamycin (mTOR) is essential for oligodendrocyte differentiation. J Neurosci 29:6367-6378.

Tyler WA, Jain MR, Cifelli SE, Li Q, Ku L, Feng Y, Li H, Wood TL (2011) Proteomic identification of novel targets regulated by the mammalian target of rapamycin pathway during oligodendrocyte differentiation. Glia 59:1754-1769.

Uddin M, Stachowiak A, Mamun AA, Tzvetkov NT, Takeda S, Atanasov AG, Bergantin LB, Abdel-Daim MM, Stankiewicz AM (2018) Autophagy and Alzheimer's disease: from molecular mechanisms to therapeutic implications. Front Aging Neurosci 10:4.

Vaccari I, Carbone A, Previtali SC, Mironova YA, Alberizzi V, Noseda R, Rivellini C, Bianchi F, Del Carro U, D’Antonio M, Lenk GM, Wrabetz L, Giger RJ, Meisler MH, Bolino A (2015) Loss of Fig4 in both Schwann 
cells and motor neurons contributes to CMT4J neuropathy. Hum Mol Genet 24:383-396.

Vontell R, Supramaniam V, Wyatt-Ashmead J, Gressens P, Rutherford M, Hagberg H, Thornton C (2015) Cellular mechanisms of toll-like receptor- 3 activation in the thalamus are associated with white matter injury in the developing brain. J Neuropathol Exp Neurol 74:273-285.

Wang Y, Liu G, Hong D, Chen F, Ji X, Cao G (2016) White matter injury in ischemic stroke. Prog Neurobiol 141:45-60.

Weiss T, Taschner-Mandl S, Bileck A, Slany A, Kromp F, Rifatbegovic F, Frech C, Windhager R, Kitzinger H, Tzou CH, Ambros PF, Gerner C, Ambros IM (2016) Proteomics and transcriptomics of peripheral nerve tissue and cells unravel new aspects of the human Schwann cell repair phenotype. Glia 64:2133-2153.

Winner B, Uyanik G, Gross C, Lange M, Schulte-Mattler W, Schuierer G, Marienhagen J, Hehr U, Winkler J (2004) Clinical progression and genetic analysis in hereditary spastic paraplegia with thin corpus callosum in spastic gait gene 11 (SPG11). Arch Neurol 61:117-121.

Wong YC, Holzbaur EL (2015) Autophagosome dynamics in neurodegeneration at a glance. J Cell Sci 128:1259-1267.

Yin Y, Li E, Sun G, Yan HQ, Foley LM, Andrzejczuk LA, Attarwala IY, Hitchens TK, Kiselyov K, Dixon CE, Sun D (2018) Effects of DHA on hip- pocampal autophagy and lysosome function after traumatic brain injury. Mol Neurobiol 55:2454-2470.

Yorimitsu T, Nair U, Yang Z, Klionsky DJ (2006) Endoplasmic reticulum stress triggers autophagy. J Biol Chem 281:30299-30304.

Zare-Shahabadi A, Masliah E, Johnson GV, Rezaei N (2015) Autophagy in Alzheimer's disease. Rev Neurosci 26:385-395.

Zhang J, Lachance V, Schaffner A, Li X, Fedick A, Kaye LE, Liao J, Rosenfeld J, Yachelevich N, Chu ML, Mitchell WG, Boles RG, Moran E, Tokita M, Gorman E, Bagley K, Zhang W, Xia F, Leduc M, Yang Y, et al. (2016) A founder mutation in VPS11 causes an autosomal recessive leukoencephalopathy linked to autophagic defects. PLoS Genet 12:e1005848.

Zhang L, Wang H (2018) Autophagy in traumatic brain injury: a new target for therapeutic intervention. Front Mol Neurosci 11:190.

Zhang Y, Chen K, Sloan SA, Bennett ML, Scholze AR, O’Keeffe S, Phatnani HP, Guarnieri P, Caneda C, Ruderisch N, Deng S, Liddelow SA, Zhang C, Daneman R, Maniatis T, Barres BA, Wu JQ (2014) An RNA-sequencing transcriptome and splicing database of glia, neurons, and vascular cells of the cerebral cortex. J Neurosci 34:11929-11947.

Zhou C, Ma K, Gao R, Mu C, Chen L, Liu Q, Luo Q, Feng D, Zhu Y, Chen Q (2017) Regulation of mATG9 trafficking by Src-and ULK1-mediated phosphorylation in basal and starvation-induced autophagy. Cell Res 27: 184-201. 